\title{
PENGGUNAAN DAN BATASAN DISKRESI DALAM PENGELOLAAN KEUANGAN DAERAH DI INDONESIA
}

\author{
Tri Suhendra Arbani
}

\author{
UIN Alauddin Makassar \\ Jl. Sultan Alauddin No. 63 Makassar Sulawesi Selatan \\ tri.suhendra@uin-alauddin.ac.id
}

\begin{abstract}
Financial regulations are important because many regional heads are involved in corruption cases due to the lack of financial technical regulations. This paper examines issues of scope and boundaries for regional financial management. The study uses normative legal research, namely research conducted on written regulations and other legal materials that are secondary data. The approach used is the statute approach, comparative approach, and conceptual approach. This written data analysis uses data management by organizing a system of written legal materials. The results of this paper outline how to use discretion. The concept of discretion is present as a middle ground from the weak system of legislation and legal vacuum. Local governments may take discretionary measures if they meet the various requirements and scope of discretion that has been regulated in government administrative laws. These restrictions on the use of discretion indicate that not everything can be taken as a discretionary measure. Restrictions on the use of discretion must not conflict with the rule of positive law and the use of discretion is only demonstrated in the public interest.
\end{abstract}

Keywords: Limitation, Discretion, Regional Finance

\begin{abstract}
Abstrak
Regulasi dibidang keuangan menjadi penting karena banyak kepala daerah yang tersangkut perkara korupsi akibat dari kurangnya regulasi teknis keuangan. Tulisan ini mengkaji permasalahan ruang lingkup dan batasan diskresi pengelolaan keuangan daerah.Penelitian inimenggunakan penelitiannormatif yuridis, yakni penelitian yang dipakai pada peraturan tertulis dan bahan-bahan hukum yang sifatnya sekunder. Pendekatan yang dipakai pendekatanstatute approach, comparative approach, dan conceptual approach. Analisis data tulisan ini menggunakan pengelolaan data dengan mengadakan sistemasi terhadap bahan-bahan hukum tertulis. Hasil dari tulisan ini menjabarkan bagaimana seyogyanya penggunaan diskresi.Konsep diskresi ini hadir menjadi jalan tengah dari lemahnya sistem perundang-undangan dan kekosongan hukum. Pemerintahan daerah boleh mengambil tindakan-tindakan diskresi jika memenuhi berbagai persyaran dan ruang lingkup dari diskresi yang telah diatur dalam Undang-Undang Administrasi Pemerintahan. Batasan penggunaan diskresi ini menunjukkan tidak semua hal dapat diambil tindakan diskresi. Pembatasan penggunaan diskresi tidak boleh bertentangan dengan normahukum positif dan pemakaian diskresi ditunjukkan untuk kepentingan umum.
\end{abstract}

Kata Kunci: Batasan, Diskresi, Keuangan Daerah 


\section{PENDAHULUAN}

Indonesia menganut sistem hukum Civil Law dimana pembentukan hukumnya berasal dari atas, dan hukum menjadi pedoman dalam mengambil tindakan. ${ }^{1}$ Setiap tindakan pemerintah tidak boleh terlepas dari aturan yang telah dibentuk. Pertanyaannya adalah bagaimana ketika dalam keadaan tertentu aturan hukumnya tidak ada sementara tindakan atau keputusan harus segara diambil. Pada prinsipnya hukum memberikan ruang gerak untuk mengambil tindakan atau keputusan ketika terjadi kekosongan hukum. Pada bidang hukum administrasi hal ini biasa disebut dengan "diskresi" yang berasal dari bahasa asing "discretion".

Diskresi atau yang dikenal juga dengan freis ermessen² berasal pada katafreibisa bermaknalepas, bebas, tidak terikat, dan merdeka. ${ }^{3}$ Penggunaan diskresi di Indonesia merupakan hal yang cukup penting untuk dikaji dalam pengaturan dan penggunaannya. Pengaturan diskresi di Indonesia sebenarnya sudah diatur melalui undang-undang, disisi lain penggunaannya juga menjadi hal yang menakutkan sebagian orang. Mengapa demikian, karena diskresi bisa menjadi hal yang serius dan bahkan berujung pada pidana. Hal ini yang menjadi ketakutan bagi sebagian kepala daerah di Indonesia dalam mengelola keuangan daerahnya.

Keuangan daerah merupakan hal paling penting dan menjadi urat nadi dalam menjalankan seluruh aktivitas pemerintahan daerah. Keuangan menjadi sumber kehidupan dan berkembangnya suatu negara begitupun daerah sehingga pengaturan dan penggunaannya harus diatur dengan baik. Pengaturan ini menjadi penting karena keuangan juga bisa menjadi ladang subur bagi para kuruptor dalam memperkaya diri sendiri dan kelompoknya.Banyaknya kepala daerah yang tersangkut korupsi menjadi bukti bahwa pengaturan dan pengawasan menjadi penting. Di tahun2017, ada 30 kepala daerah yang menjadi tersangka pada kasus korupsi diantaranya 5 wali kota/wakil wali kota, 24 bupati/ wakil bupati dan 1 orang gubernur. Dari kasus korupsi tersebut ada Rp 231 Milliar kerugian Negara dan Rp 41 Milliar nilai suap. ${ }^{4}$ Dan pada tahun 2018 sendiri ada 29 kepala daerah yang terjerat oleh Komisi Pemberantasan Korupsi (KPK) pada sejumlah kasus dugaan korupsi. ${ }^{5}$ Terjeratnya para kepala daerah menjadi persoalan dalam pengelolaan daerah, tidak bisa dipungkiri bahwa ada hasrat untuk memperkaya diri sendiri tapi disisi lain hal tersebut juga dikarenakan masih banyaknya kekosongan regulasi dalam mengatur dan mengelola keuangan daerah.

Permasalahan utama dalam pengelolaan keuangan daerah adalah kelemahan dari peraturan perundang-undangan sendiri, khususnya dibidang penganggaran.Pada penganggaran masih banyak yang belum terjabarkan kedalam peraturan daerah. Setiap daerah memiliki regulasi berbeda dalam menerbitkan perda dan dipengaruhi oleh jajaran pimpinan daerah, dan banyak dari mereka meninggalkan paradigma untuk terlepas dari juknis dari pusat. Salah satu akibat lemahnya regulasi dibidang pengeloalaan keuangan daerah adalah anggaran di tahun 2018 mencapai Rp246 triliun

\footnotetext{
${ }^{1}$ Tri SuhendraArbani, "Analisis Yuridis Cabang Pemerintahan Keempat Dalam Struktur Ketatanegaraan Di Indonesia." Jurnal Wacana Hukum Vol. 24, No. 1 (2019): 19-37.

${ }^{2}$ Freisberari tindakan yang bebas, lepas, merdeka dan tidak terika. Sementara ermessen bisa diartikan sebagai tindakan yang memiliki kebebebasan dalam menilai dan menduga serta mempertimbangkan sesuatu. Freis Ermessen (dikresionare)selanjutnya dipakai pada bidang pemerintahanuntuk melakukan tindakan tanpa harus terikat sepenuhnya pada undang-undang

${ }^{3}$ Ridwan HR, 2010, Hukum Administrasi Negara, Rajawali Pers, Jakarta, h. 177.

${ }^{4}$ Gibran Maulana Ibrahim, https://news.detik.com/berita/d-3876999/icw-korupsi-apbd-oleh-kepala-daerahterjadi-paling-banyak-di-2017, diakses pada tanggal 15 Juli 2019.

${ }^{5}$ Dylan Aprialdo Rachman, https://nasional.kompas.com/read/2018/12/18/12495661/kaleidoskop-2018-29kepala-daerah-terjerat-kasus-korupsi?page=all, diakses pada tanggal 15 Juli 2019.
} 
yang ditransfer ke daerah mengendap di bank-bank daerah. Dana yang sebesar itu seharusnya itu digunakan untuk pembangunan daerah. ${ }^{6}$ Adanya uang yang begitu besar mengendap di bank karena katakutan kepala daerah ikut terjerat kasus korupsi dan dikriminalisasi dikarenakan tidak ada regulasi teknis yang mengatur pengelolaan keuangan tersebut.

Kekosongan regulasi dalam sistem hukum di Indonesia sebenarnya diberikan ruang untuk mengambil diskresi. Untuk kebijakan diskresi sendiri bisa diambil dan dilaksanakan akan tetapi dengan mempertimbangkan beberapa aspek seperti adanya kekosongan hukum atau peraturan yang mengatur kebijakan dan adanya kondisi yang mendesak. “Diskresi pada dasarnya tidak boleh digunakan apabila peraturan tersebut ada dan kondisi dalam keadaan normal. Tindakan diskresi yang diambil Kepala Daerah bisa terjadi kapan saja. Agar tidak terjadi pelanggaran, Undang-Undang Nomor 30 Tahun 2014 tentang Administrasi Pemerintahan, Kepala Daerah harus memahami konsep diskresi yang ada di dalamnya. ${ }^{7}$

Undang-Undang Nomor 30 Tahun 2014 yang mengatur mengenai Pembatasan tindakan diskresi didalamnya menegaskan penggunaan freis ermessenmerupakan norma yang mengikat sehingga bisa digunakan dalam menghindari dari pejabat dalam menyalahgunakan wewenang yang ada dan melekat padanya (detournement de pouvoir) serta segala tindakan yang sewenangwenang. Salah satu dari tujuan utama dituangkannya diskresi dalam Undang-Undang Nomor 30 Tahun 2014 ialah semata-mata menciptakan dan menunjang kepastian hukum serta jaminan perlindungan hukum di bidang administrasi negara khususnya bagi warga negara. ${ }^{8}$

Undang-Undang Nomor30 Tahun 2014 tentang Administrasi Pemerintahan, pemberian diskresi yang dilakukan oleh pejabat pemerintahan diatur secara tegas. Pembatasan diskresi bisa dilihat dalam Pasal 24 Undang-Undang Nomor30 Tahun 2014 yang berbunyi ${ }^{9}$ : Syarat bagi Pejabat Pemerintahan untuk menggunakan diskresi harus: Sesuai dengan tujuan diskresi seperti yang ada Pasal 22 ayat (2), Tindakan tersebut sejalan dengan ketentuan peraturan perundangundangan, khususnya sesuai dengan AUPB, memilki alasan dan landasan yang objektif, tidak membuat adanya konflik kepentingan, serta harusdilakukan dengan suatu iktikad yang baik.

Berdasarkan uraian diatas pada tulisan ini akan berfokus pada permasalahan yang mengatur diskresi dalam pengelolaan keuangan daerah dan batasan diskresi.

\section{TELAAH KONSEP}

\section{Diskresi}

Freies Ermessenatau yang beberapa ahli juga menyebutnya sebagi diskresi bisa bermakna tindakan yang bebas dalam mempertimbangkan mempertimbangkan, bebas mengambil keputusan dan bebas menilai serta bebas menduga. Secara bahasan diskresi dapat disebut sebagai(Pouvoir Discretionare: Perancis, Discretionary Power: Inggris). ${ }^{10}$ Freis Ermessen (dikresionare)

\footnotetext{
${ }^{6}$ Joko Panji Sasongko, https://www.cnnindonesia.com/nasional/20160725225155-12-146983/kpk-ingatkan-pemda-hatihati-beri-diskresi, diakses pada tanggal 16 Juli 2019.

${ }^{7}$ Ibid

${ }^{8}$ I Gusti Ayu Apsari Hadi, Pertanggungjawabn Pejabat Pemerintahan Dalam Tindakan Diskresi Pasca Berlakunya Undang-Undang No. 30 Tahun 2014 Tentang Administrasi Pemerintahan, Kertha Patrika, Volume 39, Nomor 1, April 2017, Jurnal Ilmiah Fakultas Hukum Universitas Udayana, h. 40.

9 Pasal 24 Undang-Undang Nomor 30 Tahun 2014 Tentang Administrasi Pemerintahan, Lembaran Negara Republik Indonesia Tahun 2014 Nomor 292, Tambahan Lembaran Negara Republik Indonesia Nomor 5601.

${ }^{10}$ Peter Mahmud Marzuki, 2005, Penelitian Hukum, Kencana Prenada Media Group, Jakarta, h. 93-95.
} 
kemudian digunakan dalam bidang pemerintahan sebagai ruang bagi pejabat atau badan-badan administrasi negara dalam mengambil berbagai tindakan tanpa harus terikat sepenuhnya pada undang-undang. ${ }^{11}$

Dalam Black's Law Dictionary, disebutkan bahwa ${ }^{12}$ : Kebijaksanaan ketika diterapkan pada pejabat publik, kebijaksanaan berarti kekuasaan atau hak yang diberikan kepada mereka oleh hukum yang bertindak secara resmi dalam keadaan tertentu sesuai dengan dikte penilaian dan hati nurani mereka sendiri, tidak terkendali oleh penilaian atau hati nurani orang lain. Sebagaimana diterapkan pada pejabat publik berarti kekuatan untuk bertindak dalam kapasitas resmi dengan cara yang tampaknya adil dan layak dalam situasi tersebut

Definisi diatas pada intinya menyebutkan bahwa pejabat publik diberi wewenang dalam mengambil keputusan sendiri yang didasarkan atas hukum dan perasaan atau keyakinan pejabat publik itu sendiri. Hal senada juga dikemukakan oleh Roscoe Pound, bahwa "discretion is an authority conferred by law to act in certain conditions or situations in accordance with a official's or an official agency's own considered judgment and conscience. It is an idea of morals, belonging to the twigh light zones between law and morals". ${ }^{13}$

Penggunaan diskresi pada umumnya harus digunakan dalam keadaan mendesak. Hal ini sejalan dengan pendapat dari Marcus Lukman yang mengatakan bahwa untuk permasalahan penting yang mendesak, setidaknya mengandung unsur-unsur seperti: ${ }^{14}$

a. Permasalahan tersebut harus mengenai kebutuhan dan menjadi kepentingan umum;

b. Munculnya suatu permasalahan yang tidak terduga atau tiba-tiba, dan bebeda dari rencana utama;

c. Dalam menyelesaikan permasalahan, suatu peraturan masih bersifat umum dan belum ada peraturan teknisnya, sehingga administrasi Negara memiliki kebebasan untuk menyelesaikan atas pertimbangan-pertimbangan yang diambil;

d. Prosedurnya dalam proses penyelesaian administrasinya tidak bisa dengan cara normal, atau apabila diselesaikan melalui prsedur administasi normal malah kurang berdaya guna dan berhasil guna.

\section{Keuangan Daerah}

Pengelolaan keuangan negara dan daerah telah dituangkan di beberapa peraturan perundang-undangan. Pengaturannya diatur di undang-undang dasar negara Republik Indonesia, undang-undang dan peraturan teknis pelaksananya. Pengaturan di undang-undang diatur dalam :

1) Undang-Undang Nomor 20 Tahun 1997 tentang Penerimaan Negara Bukan Pajak

2) Undang-Undang Nomor 17 Tahun 2003 tentang Keuangan Negara

3) Undang-Undang Nomor 1 Tahun 2004 tentang Perbendaharaan Negara

4) Undang-Undang Nomor 15 Tahun 2004 tentang Pemeriksaan Pengelolaan dan Tanggung Jawab Keuangan

5) Undang-Undang Nomor 33Tahun 2004 tentang Perimbangan Keuangan Antara Pemerintah Pusat dan Pemerintah Daerah

\footnotetext{
${ }^{11}$ Ridwan HR, 2010, Hukum Administrasi Negara, Penerbit, Rajawali Pers, Jakarta, h. 177.

${ }^{12}$ Harry Campbel Black, 1979, Black's Law Dictionary, West Publishing Co, h. 419.

${ }^{13}$ Roscoe Pound, 1984, Discretionary Justice, An Introduction in Criminal Justice, Charles C., Thomas Publisher, h. 3.

${ }^{14}$ S.F.Marbun, 2001, Pembentukan, Pemberlakuan, Dan Peranan Asas-asas Umum Pemerintahan yang Layak dalam Menjelmakan Pemerintahan Yang Baik dan Bersih di Indonesia, Disertasi, Universitas Padjajaran Bandung, h. 17.
} 


\section{METODE PENELITIAN}

Pada penelitian ini menggunakan jenis penelitian normatif yuridis, penelitian yang dilakukan dan dikaji pada suatu peraturan tertulis dan bahan hukum lain yang sifatnya sekunder.

Pada penelitian ini hukum ini memakai pendekatan :Pendekatan Undang-Undang (statute approach), pendekatan komparatif (comparative approach), dan pendekatan konseptual (conceptual approach). Pendekatan ini digunakan untuk mengkaji mengenai segala aturan, norma serta asas yang menyangkut terkait diskresi. Selain itu, pendekatan komparatif dan pendekatan konseptual mencoba mengkaji mengenai konsep perbandingan diskresi negara lain kemudian dirumuskan dalam satu konsep baru dan teori yang baru.

Pada penelitian ini menggunakan jenis dan sumber data serta alat pengumpulan data yakni suatu studi kepustakaan dimana segala sumber data yang didapatkan dari bahan hukum primer berupa peraturan perundang-undangan yang berkaitan dengan masalah yang diteliti, antara lain: UUD Negara Republik Indonesia Tahun 1945, Peraturan Perundang-undangan lain yang terkait dengan penelitian ini.Bahan hukum sekunder, yaitu bersumber dari berbagai data pendukung yang sifatnya membantu data utama sehingga dapat melengkapi dan memahami bahan-bahan hukum primer. Bahan hukum yang terakhir adalah bahan hukum tersier yang sifatnya pendukung dari semua data yanga ada.Teknik analisis data pada tulisan menggunakan pengelolaan data pada hakikatnya kegiatan untuk mengadakan sistemasi terhadap bahanbahan hukum tertulis.

\section{PEMBAHASAN}

\section{Penggunaan Diskresi dalam Pengelolaan Keuangan Daerah}

a. Pengaturan Diskresi

Secara bahasa bersumber dari dua kata freies dan Ermessen.Freis berari tindakan yang bebas, lepas, merdeka dan tidak terikat. Sementara ermessen bisa diartikan sebagai tindakan yang memiliki kebebebasan dalam menilai dan menduga serta mempertimbangkan sesuatu. Freis Ermessen (dikresionare)selanjutnya dipakai pada bidang pemerintahan sebagai salah satu saran yang memberikan ruang bergerak bagi pejabat atau badan-badan administrasi negara untuk melakukan tindakan tanpa harus terikat sepenuhnya pada undang-undang. ${ }^{15}$ Secara bahasa diskresi disebut (Pouvoir Discretionare: Perancis, Discretionary Power: Inggris). ${ }^{16}$

Menurut kamus Black's Law Dictionary, disebutkan bahwa ${ }^{17}$ : Kebijaksanaan ketika diterapkan pada pejabat publik, kebijaksanaan berarti kekuasaan atau hak yang diberikan kepada mereka oleh hukum yang bertindak secara resmi dalam keadaan tertentu sesuai dengan dikte penilaian dan hati nurani mereka sendiri, tidak terkendali oleh penilaian atau hati nurani orang lain. Sebagaimana diterapkan pada pejabat publik berarti kekuatan untuk bertindak dalam kapasitas resmi dengan cara yang tampaknya adil dan layak dalam situasi tersebut.

Definisi diatas bersifat umum yang pada intinya menekankan pada wewenang pejabat publik untuk mengambil keputusan sendiri yang didasarkanatas hukum dan perasaan atau keyakinan pejabat publik itu sendiri. Hal senada juga dikemukakan oleh Roscoe Pound, bahwa "discretion is an authority conferred by law to act in certain conditions or situations in accordance with a

\footnotetext{
${ }^{15}$ Ridwan HR, 2010, Hukum Administrasi Negara, Penerbit, Rajawali Pers, Jakarta, hlm. 177

${ }^{16}$ Peter Mahmud Marzuki, Op.,Cit, h. 93-95.

${ }^{17}$ Harry Campbel Black, Op.,Cit, h. 419.
} 
official's or an official agency's own considered judgment and conscience. It is an idea of morals, belonging to the twigh light zones between law and morals". ${ }^{18}$

Oleh Thomas J. Aaron, disebutkan bahwa : "discretion is power authority confered by law to acton on the basic of judgement or conscience, and its use more an ideal of morals than law" ${ }^{19}$ Yang dapat diartikan sebagai suatu kekuasaan atau wewenang yang dilakukan berdasarkan hukum atas pertimbangan dan keyakinannya danlebih menekankan moral daripada pertimbangan hukum.

Di Indonesia sendiri pengaturan terhadap diskresi diatur dalam peraturan perundangundangan di Undang-Undang Nomor 30 Tahun 2014 tentang Administrasi Pemerintahan. Dijelaskan bahwa diskresi adalah Keputusan dan/atau Tindakan yang ditetapkan dan/atau dilakukan oleh Pejabat Pemerintahan untuk mengatasi persoalan konkret yang dihadapi dalam penyelenggaraan pemerintahan dalam hal peraturan perundang-undangan yang memberikan pilihan, tidak mengatur, tidak lengkap atau tidak jelas, dan/atau adanya stagnasi pemerintahan. ${ }^{20}$

Pada bidang pemerintahan penggunaan diskresi terkdang menimbulkan berbagai akibat hukum. Ketidakmampuan dan ketidak jelian para aparat pemerintah dalam mengambil keputusan yang berupa diskresi bisa menjadi boomerang yang justru menyerang kembali. Banyak kasus aparat yang tersandung kasus pidana karena permasalahan tersebut khususnya persoalan keuangan daerah. Pejabat keuangan dari pemerintah daerah ketakutan dalam mengambil diskresi dikarenakan adanya kriminalisasi dikemudian hari oleh aparat.

Pada hakikatnya pengambilan tindakan diskresi dapat diambil oleh Pejabat Pemerintahan yang berwenang. Serta setiap tindakan Diskresi Pejabat Pemerintahan bertujuan untuk: a. melancarkan penyelenggaraan pemerintahan; b. mengisi kekosongan hukum; c. memberikan kepastian hukum; dan d. mengatasi stagnasi pemerintahan dalam keadaan tertentu guna kemanfaatan dan kepentingan umum. ${ }^{21}$ Pada pasal selanjutnya dijelaskan bahwa Diskresi Pejabat Pemerintahan meliputi: a.pengambilan Keputusan dan/atau Tindakan berdasarkan ketentuan peraturan perundang-undangan yang memberikan suatu pilihan Keputusan dan/atau Tindakan; b.pengambilan Keputusan dan/atau Tindakan karena peraturan perundang-undangan tidak mengatur; c.pengambilan Keputusan dan/atau Tindakan karena peraturan perundang-undangan tidak lengkap atau tidak jelas; dan d.pengambilan Keputusan dan/atau Tindakan karena adanya stagnasi pemerintahan guna kepentingan yang lebih luas. ${ }^{22}$

Aturan diatas memberikan gambaran tentang penggunaan diskresi oleh pejabat pemerintahan khususnya pejabat pengelola keuangan daerah. Ruang lingkup diskresi sebenarnya bisa menjadi acuan tentang kapan dan bagaimana mekanisme dalam menggunakan diskresi. Dari poin-poin tersebut menjadi prasyarat yang ketat bagi aparat pemerintah karena hal tersebut akan menimbulkan akibat hukum baru. Akibat hukum yang timbul dari diskresi akan berimplikasi pada pelaksanaan jenjang pemerintahan sehingga efeknya juga akan terasa di semua aspek pemerintahan. Oleh karena itu, diskresi tidak boleh digunakan setiap saat dan bukan pada keadaan tertentu.

\footnotetext{
${ }^{18}$ Roscoe Pound,Op.,Cit, h. 3.

${ }^{19}$ Tomas J. Aaron, 1960, The Control of Police Discretions, Springfield, Charles C. Thomas, h. 9.

${ }^{20}$ Pasal 1 angka (9) Undang-Undang Nomor 30 Tahun 2014 Tentang Administrasi Pemerintahan, Lembaran Negara Republik Indonesia Tahun 2014 Nomor 292, Tambahan Lembaran Negara Republik Indonesia Nomor 5601.

${ }^{21}$ Pasal 22 Ayat (1) Dan (2) Undang-Undang Nomor 30 Tahun 2014 Tentang Administrasi Pemerintahan, Lembaran Negara Republik Indonesia Tahun 2014 Nomor 292, Tambahan Lembaran Negara Republik Indonesia Nomor 5601.

${ }^{22}$ Pasal 23 Undang-Undang Nomor 30 Tahun 2014 Tentang Administrasi Pemerintahan, Lembaran Negara Republik Indonesia Tahun 2014 Nomor 292, Tambahan Lembaran Negara Republik Indonesia Nomor 5601.
} 
Agar lebih aman dalam mengambil diskresi adalah jika memenuhi persyaratan yang adadi Pasal 24Undang-UndangAdministrasi Pemerintahan, didalamnya di jelaskan bahwa Diskresi harus memenuhi syarat: sesuai sebagiaman tujuan utama dari diskresi yang berada pada Pasal 22 ayat (2) Undang-Undang Administrasi Pemerintahan, yang kedua yakni diskresi tidak bertentangan dengan suatu peraaturan perundang-undangan, ketiga diskresi sesuai dengan Asas Umum Pemerintahan yang baik, keempat diskresi harus berdasar alasan-alasan yang objektif, kelima diskresi tidak menimbulkan konflik kepentingan dan yang terakhir diskresi sesaui dengan iktikad baik. ${ }^{23}$

Konsep diskresi ini hadir menjadi jalan tengah dari lemahnya sistem perundang-undangan dan kekosongan hukum. Diskresi lahir dari aliran Rechtsvinding yang menyadari bahwa pembuat undang-undang tidak dapat mengikuti kecepatan dari gerak masyarakat atau proses perkembangan sosial yang sangat dinamis, sehingga undang-undang selalu ketinggalan. Undangundang tidak dapat lengkap dan tidak dapat mencangkup segala-galanya. Disini selalu ada leemten (kekosongan dalam undang-undang), sehingga harus dipahami dengan jalan mengadakan rekonstruksi hukum. ${ }^{24}$

Jadi pada intinya pejabat negara khususnya pemerintahan daerah boleh mengambil tindakan-tindakan diskresi jika memenuhi berbagai persyaran dan ruang lingkup dari diskresi itu sendiri yang telah diatur dalam Undang-Undang Administrasi Pemerintahan. Pejabat pemerintah daerah tidak perlu ragu selama diskresi diambil atas kepentingan masyarakat dan dapat dipertanggungjawabkan segala hal dari pembentukannya.

\section{b. Pengaturan Diskresi Keuangan Daerah}

Pengaturan diskresi terhadap keuangan Negara berkaitan dengan pengelolaan keuangan Negara dan keuangan daerah. Hal ini dituangkan dalam beberapa peraturan perundangundangan dan norma hukum lainnya. Pengaturannya diatur di UUD Negara Republik Indonesia, undang-undang dan peraturan teknis pelaksananya. Pengaturan di undang-undang diatur dalam :

1) Undang-Undang Nomor 20 Tahun 1997 tentang Penerimaan Negara Bukan Pajak

2) Undang-Undang Nomor 17 Tahun 2003 tentang Keuangan Negara

3) Undang-Undang Nomor 1 Tahun 2004 tentang Perbendaharaan Negara

4) Undang-Undang Nomor 15 Tahun 2004 tentang Pemeriksaan Pengelolaan dan Tanggung Jawab Keuangan

5) Undang-Undang Nomor 33Tahun 2004 tentang Perimbangan Keuangan Antara Pemerintah Pusat dan Pemerintah Daerah

Dari kelima undang-undang diatas pada dasarnya mengatur mengenai keuangan negara dalam aspek luas. Pengaturan pada tingkat teknis diatur dalam berbagai peraturan pemerintah, peraturan presiden, dan peraturan daerah. Meskipun sudah ada regulasi dari tingkat atas sampai bawah, tetap akanada ruang kosong regulasi dalam mengelola keuangan daerah.

Persoalan diskresi dalam pengelolaan keuangan juga diberikan ruang dalam mengambil keputusan. Pada aturannya mengatur bahwa Diskresi dalam penggunaanyamemiliki potensi

\footnotetext{
${ }^{23}$ Pasal 24 Undang-Undang Nomor 30 Tahun 2014 Tentang Administrasi Pemerintahan, Lembaran Negara Republik Indonesia Tahun 2014 Nomor 292, Tambahan Lembaran Negara Republik Indonesia Nomor 5601.

${ }^{24}$ Arfan Faiz Muhlizi, Reformulasi Diskresi dalam Penataan Hukum Administrasi, Jurnal Rechtvinding Media Pembinaan Hukum Nasional, Volume 1 Nomor 1 Januari-April 2012, h. 102.
} 
untuk mengubah beberap alokasi anggaran yang wajib memperoleh persetujuan dari atasan Pejabat sesuai dengan ketentuan peraturan perundang-undangan. Persetujuan dilakukan apabila penggunaan Diskresi berdasarkan ketentuan:

1) Pengambilan Keputusan dan/atau Tindakan berdasarkan ketentuan peraturan perundangundangan yang memberikan suatu pilihan Keputusan dan/atau Tindakan;

2) Pengambilan Keputusan dan/atau Tindakan karena peraturan perundang-undangan tidak lengkap atau tidak jelas

3) Pengambilan Keputusan dan/atau Tindakan karena peraturan perundang-undangan tidak mengatur;

Aspek terpenting dalam mengambil diskresi terhadap pengelolaan keuangan daerah adalah menggunakan kewenangan pada tempatnya. Selama ini banyak pejabat yang tersangkut korupsi atau kasus lainnya adalah penyalahgunaan kekuasaan. Untuk menghindari upaya penyalahgunaan wewenang, hukum adminitrasi telah memberikan upaya preventif dan represif sehingga peluang terjadinya suatu korupsi dapat dihindarkan. ${ }^{25}$

Selama tidak terdapat penyalahgunaan kekuasaan untuk kepentingan sendiri dan kepentingan kelompok atau golongan tertentu, maka diskresi secara aturan dan asasnya boleh di gunakan tanpa ada keraguan dari konsekuensi hukum kedepannya.

\section{Batasan Penggunaan Diskresi dalam Pengelolaan Keuangan Daerah}

Diskresi bukan berarti menggunakan keleluasaan yang ada padanya tanpa ada batasan. Pada prinsipnya kekuasaan atau wewenang tersebut dilakukan berdasarkan hukum atas pertimbangan dan keyakinannya dan lebih menekankan moral daripada pertimbangan hukum. Meskipun diskresi memberikan ruang unutk pengambilan tindakan diluar aturan hukum, akan tetapi bukan tanpa masalah. Sebab adanya suatu tindakan bebas juga berarti adanya suatu peluang untuk menyahgunakan suatu wewenang(detournement de pouvoir) atau tindakan sewenangwenang (willekeur) yang pada akhirnya bisa memberikan kerugian khususnya keuangan negara. Mengenai dasar pelaksanan fungsi dari hukum adminitasi Negara berkaitan dengan konsep Negara kesejahteraanwelfare stateyang merupakan alternatif bagi penyelenggaraan yang bersih di pemerintahan. ${ }^{26}$

Pemberian kekuasaan untuk bertindak secara bebas tentunya harus diberikan batasan sehingga penyalahgunaan wewenang (detournement de pouvoir) tidak terjadi. Pada Undang-Undang Nomor30 Tahun 2014 tentang Administrasi Pemerintahan, pemberian diskresi yang dilakukan oleh pejabat pemerintahan diatur secara tegas di dalam pasal-pasalnya.

Tujuan utama dari dituangkannya diskresi dalam Undang-Undang Nomor30 Tahun 2014 ialah semata-mata menciptakan dan menunjang kepastian hukum serta jaminan perlindungan hukum di bidang administrasi negara khususnya bagi warga negara. ${ }^{27}$ Pembatasan diskresi bisa dilihat dalam Pasal 24 Undang-Undang Administrasi Pemerintahan, didalamnya di jelaskan

\footnotetext{
${ }^{25}$ Philipus M. Hadjon, 2011, "Kisi-Kisi Hukum Administrasi Dalam Konteks Tindak Pidana Korupsi," dalam Hukum Administrasi Dan Tindak Pidana Korupsi, Gajah Mada University Press, Jogjakarta, h.2.

${ }^{26}$ Jazim Hamidi, Penerapan Asas-asas Umum Penyelenggaraan Pemerintahan Yang Layak (AAUPL) di Lingkungan Peradilan Administrasi di Indonesia (Upaya Menuju “Clean and Stable Government"), Citra Aditya Bakti, Bandung, 1999, h. 33.

${ }^{27}$ I Gusti Ayu Apsari Hadi, Op.,Cit, h. 40.
} 
bahwa Diskresi harus memenuhi syarat: sesuai sebagiaman tujuan utama dari diskresi yang berada pada Pasal 22 ayat (2) Undang-Undang Administrasi Pemerintahan, yang kedua yakni diskresi tidak bertentangan dengan suatu peraturan perundang-undangan, ketiga diskresi sesuai dengan Asas Umum Pemerintahan yang baik, keempat diskresi harus berdasar alasan-alasan yang objektif, kelima diskresi tidak menimbulkan konflik kepentingan dan yang terakhir diskresi sesuai dengan iktikad baik. ${ }^{28}$

Batasan penggunaan diskresi ini menunjukkan tidak semua hal dapat diambil tindakan diskresi. Menurut pandangan dari Muchsan pembatasan penggunaan diskresi atau fies ermessenadalah sebagai berikut $:^{29}$

1. Freis Ermessenharus sesuai dan tidak boleh bertentangan dengan sistem hukum yang berlaku pada suatu Negara;

2. Freis Ermessen hanya ditunjukkan untuk dan demi kepentingan umum.

Pandangan diatas memberikan gambaran yang jelas bahwa sekalipun ada ruang dalam mengambil tindakan diskresi, akan tetapi tetap harus berpatokan pada sistem hukum yang berlaku, dan tidak kalah pentingnya adalah untuk kepentingan umum. Kepentingan umum yang dimaksud dalam hal ini menurut penulis adalah kepentingan umum yang sifatnya berpengaruh langsung dalam semua bidang kehidupan masyarakat. Bidang masyarakat yang dimaksud adalah bidang ekonomi, sosial, politik dan budaya. Selain itu kepentingan umum yang harus dikedepankan ialah akibat hukum yang akan berdampak kepada masyarakat khususnya pengelolaan keuangan daerah. Berkembang tidaknya perekonomian daerah itu tergantung dari bagaimana kepala daerah dapat mengelola dan mengatur semua sendi keuangannya.

Pembatasan ini diatur karena diskresi akan memiliki akibat hukum jika melampaui wewenang. Pasal 30Undang-Undang Administrasi pemerintahan mengenai akibat hukum diskresi bahwa diskresi dapat dikategorikan melampaui Wewenang apabila: tindakan tersebut melewati atau melampaui dari batas waktu dari berlakunya suatu wewenang yang diatur dalam peraturan perundang-undangan, tindakan dsikresi tersebut melewati batas wilayah berlakunya Wewenang yang diatur dalam peraturan perundang-undangan yang berlaku. Akibat hukum diskresi dikategorikan menjadi tidak sah apabila melampauisegala wewenang seperti yang telah disebutkan diatas.

Merujuk pada penjelasan diatas, salah satu hal yang menarik dan dikaji bersamaadalah dengan adanya Putusan Mahkamah Konstitusi Nomor 25/PUU-XIV/2016 mengenai pengujian Undang-Undang Nomor 31 Tahun 1999 dan Undang-Undang Nomor 20 Tahun 2001 terkait penetapan diskresi yang dilakukan oleh kepala daerah. Untuk melaksanakan setiap program dari pemerintah, maka suatu kepala daerah bisa menetapkan dan mengambil tindakan diskresi pada penggunaan anggaran selama belumada regulasi dan aturan perundang-undangan yang mengaturnya. ${ }^{30}$

\footnotetext{
${ }^{28}$ Pasal 24 Undang-Undang Nomor 30 Tahun 2014 Tentang Administrasi Pemerintahan, Lembaran Negara Republik Indonesia Tahun 2014 Nomor 292, Tambahan Lembaran Negara Republik Indonesia Nomor 5601.

${ }^{29}$ Muchsan, 1981, Beberapa Catatan tentang Hukum Administrasi Negara dan Peradilan Administrasi di Indonesia, Liberty, Yogyakarta, h. 28.

${ }^{30}$ Zaki Ulya, Pertanggungjawaban Pejabat Pemerintahan dalam Menetapkan Diskresi (Studi terhadap Putusan Mahkamah Konstitusi Nomor 25/PUU-XIV/2016), Jurnal Hukum Ius Quia Iustum No.3 VOL 24 Juli 2017. h. 421.
} 
Kedepannya untuk upaya dan tindakan pencegahan, maka hukum administarasi memberikan ruang agar penyalahgunaan kewenagan atau kekuasaan dapat dicegah. ${ }^{31}$ Hal yang menarik ditelaah dari pendapat dari Romli Atmasasmita yang mengatakan bahwa penyalahgunaan wewenang baik dalam Undang-Undang TIPIKOR denganUndang-Undang Administrasi Negara perlu dibedakan. Perkembangan saat ini yakni dengan adanya Judicial Review Putusan Mahkamah Konstitusi Nomor 25/PUU-XIV/2016, yang menyatakan penegak hukum harus membuktikan adanya kerugian negara sebagaimana yang terdapat dalam Pasal 2 ayat (1) dan Pasal 3 UndangUndang Tipikor. Sehingga kerugian negara dalam perkara korupsi tidak bisa lagi bersifat potensi (potential loss)..$^{32}$

Dari pandangan Romli Atmasasmita di atas, kita bisa melihat bahwa putusan Mahkamah Konstitusi Nomor 25/PUU-XIV/2016 memberikan perbedaan terkait ruang gerak yang luas bagi pejabat publik atau pejabat pemerintahan dalam menerbitkan suatu diskresi. Setiap pejabat pemerintahan yang telah menerbitkan diskresi dapat memberikan laporan keuangannya baik kepada parlemen daerah maupun kepada publik sebagai bagian asas transparansi dan akuntabilitas,hal tersebut merupakan manifestasi dari (AUPB).

Dibalik kebutuhan instrument hukum karena kekosongan hukum sehingga diskresi menjadi penting, tetapi diaspek lain diskresi dapat menjadi pisau yang memiliki fungsi ganda tergantung siapa yang memakainya. Ketika dipegang oleh yang haus akan kekuasaan dan kekayaan, maka yang muncul adalah upaya untuk melakukan korupsi secara terselubung. Bila diskresi dipegang oleh pimpinan daerah yang memiliki komitmen kuat dalam memajukan daerahnya, maka akan yang ada adalah penguatan sistem dan regulasi keuangan yang pada akhirnya akan menciptakan kesejahtraan bagi masyarakat. Terlepas dari penting atau tidaknya diskresi dan batasan diskresi itu sendiri, hal yang tidak kalah pentingnya ialah bagaiamana keuangan daerah dapat dikelola dengan baik entah itu dengan istrumen hukum yang telah ada maupun instrumen hukum yang tambahan seperti diskresi.

\section{PENUTUP}

Konsep diskresi ini hadir menjadi jalan tengah dari lemahnya sistem perundang-undangan dan kekosongan hukum. Diskresi lahir dari aliran Rechtsvinding yang menyadari bahwa pembuat undang-undang tidak dapat mengikuti kecepatan dari gerak masyarakat atau proses perkembangan sosial yang sangat dinamis, sehingga undang-undang selalu ketinggalan. Undangundang tidak dapat lengkap dan tidak dapat mencangkup segala-galanya. Disini selalu ada leemten (kekosongan dalam undang-undang), sehingga harus dipahami dengan jalan mengadakan rekonstruksi hukum. Jadi pada intinya pejabat negara khususnya pemerintahan daerah boleh mengambil tindakan-tindakan diskresi jika memenuhi berbagai persyaran dan ruang lingkup dari diskresi itu sendiri yang telah diatur dalam Undang-Undang Administrasi Pemerintahan. Pejabat pemerintah daerah tidak perlu ragu selama diskresi diambil atas kepentingan masyarakat dan dapat dipertanggungjawabkan segala hal dari pembentukannya

Batasan penggunaan diskresi ini menunjukkan tidak semua hal dapat diambil tindakan diskresi. Pembatasan penggunaan freis ermessen atau diskresi pada intinya mencangkup

\footnotetext{
${ }^{31}$ Philipus M. Hadjon, Op.,Cit, h. 2.

${ }^{32}$ Romli Atmasasmita, 2015, "Pencegahan Dan Pemberantasan Korupsi Dalam Tugas Kedinasan (Pasca Undang-Undang Nomor 30 Tahun 2014)" in OC. Kaligis, Alumni, Bandung, h. 92.
} 
penggunaan freis ermessen tidak boleh bertentangan dengan sistem hukum yang berlaku (kaidah hukum positif) dan penggunaan freis ermessen hanya ditunjukkan demi kepentingan umum. Pandangan ini memberikan gambaran yang jelas bahwa sekalipun ada ruang dalam mengambil tindakan diskresi, akan tetapi tetap harus berpatokan pada sistem hukum yang berlaku, dan tidak kalah pentingnya adalah untuk kepentingan umum. Kepentingan umum yang dimaksud dalam hal ini menurut penulis adalah kepentingan umum yang sifatnya berpengaruh langsung dalam semua bidang kehidupan masyarakat. Bidang masyarakat yang dimaksud adalah bidang ekonomi, sosial, politik dan budaya. Selain itu kepentingan umum yang harus dikedepankan ialah akibat hukum yang akan berdampak kepada masyarakat khususnya pengelolaan keuangan daerah. Berkembang tidaknya perekonomian daerah itu tergantung dari bagaimana kepala daerah dapat mengelola dan mengatur semua sendi keuangannya.

\section{DAFTAR PUSTAKA}

\section{Buku :}

Ridwan HR, 2010, Hukum Administrasi Negara, Rajawali Pers, Jakarta.

Mahmud Marzuki, Peter, 2005, Penelitian Hukum, Jakarta : Kencana Prenada Media Group.

Campbel Black, Harry, 1979, Black's Law Dictionary, West Publishing Co.

Pound, Roscoe, dalam Howard Abadiensky, 1984, Discretionary Justice, An Introduction in Criminal Justice, Charles C., Thomas Publisher.

J. Aaron, Tomas, 1960, The Control of Police Discretions, Springfield, Charles C. Thomas.

Hamidi, Jazim, 1999, Penerapan Asas-asas Umum Penyelenggaraan Pemerintahan Yang Layak (AAUPL) di Lingkungan Peradilan Administrasi di Indonesia (Upaya Menuju "Clean and Stable Government"), Bandung :Citra Aditya Bakti.

Muchsan, 1981, Beberapa Catatan tentang Hukum Administrasi Negara dan Peradilan Administrasi di Indonesia, Yogyakarta :Liberty.

M. Hadjon, Philipus, 2011, "Kisi-Kisi Hukum Administrasi Dalam Konteks Tindak Pidana Korupsi," dalam Hukum Administrasi Dan Tindak Pidana Korupsi, Yogyakarta :Gajah Mada University Press.

Atmasasmita, Romli, 2015, "Pencegahan Dan Pemberantasan Korupsi Dalam Tugas Kedinasan (Pasca Undang-Undang Nomor 30 Tahun 2014)" in OC. Kaligis, Bandung :Alumni.

S.F.Marbun, 2001, Pembentukan, Pemberlakuan, Dan Peranan Asas-asas Umum Pemerintahan yang Layak dalam Menjelmakan Pemerintahan Yang Baik dan Bersih di Indonesia, Disertasi, Bandung : Universitas Padjajaran.

\section{Jurnal :}

Tri Suhendra Arbani, "Analisis Yuridis Cabang Pemerintahan Keempat Dalam Struktur Ketatanegaraan Di Indonesia." Jurnal Wacana Hukum Vol. 24, No. 1 (2019): 19-37.

I Gusti Ayu Apsari Hadi, Pertanggungjawaban Pejabat Pemerintahan Dalam Tindakan Diskresi Pasca Berlakunya Undang-Undang Nomor 30 Tahun 2014 Tentang Administrasi Pemerintahan, Kertha Patrika, Volume 39, Nomor 1, April 2017, Jurnal Ilmiah Fakultas Hukum Universitas Udayana.

Arfan Faiz Muhlizi, Reformulasi Diskresi dalam Penataan Hukum Administrasi, Jurnal Rechtvinding Media Pembinaan Hukum Nasional, Volume 1 Nomor 1 Januari-April 2012. 


\section{Website:}

Gibran Maulana Ibrahim, https://news.detik.com/berita/d-3876999/icw-korupsi-apbd-oleh-kepaladaerah-terjadi-paling-banyak-di-2017, diakses pada tanggal 15 Juli 2019.

Dylan Aprialdo Rachman, https://nasional.kompas.com/read/2018/12/18/12495661/kaleidoskop2018-29-kepala-daerah-terjerat-kasus-korupsi?page=all, diakses pada tanggal 15 Juli 2019.

Joko Panji Sasongko, https://www.cnnindonesia.com/nasional/20160725225155-12-146983/kpkingatkan-pemda-hati-hati-beri-diskresi, diakses pada tanggal 16 Juli 2019

\section{Peraturan Perundang-Undangan:}

Pasal 24 Undang-Undang Republik Indonesia Nomor 30 Tahun 2014 Tentang Administrasi Pemerintahan, Lembaran Negara Republik Indonesia Tahun 2014 Nomor 292, Tambahan Lembaran Negara Republik Indonesia Nomor 5601.

Zaki Ulya, Pertanggungjawaban Pejabat Pemerintahan dalam Menetapkan Diskresi (Studi terhadap Putusan Mahkamah Konstitusi Nomor 25/PUU-XIV/2016), Jurnal Hukum Ius Quia Iustum No.3 VOL 24 Juli 2017. 